\title{
EFFECT OF MICROPROPAGATION CONDITIONS ON ADVENTITIOUS BUDS FORMATION AND THE CIRCADIAN EXPRESSION OF THE ACO013229.1 GENE IN ANANAS COMOSUS
}

\author{
Manal E.A.E. Ahmed ${ }^{1}$, Reda E.E. Abo El-Fadl ${ }^{1}$, Mohamed N.S. \\ Suliman $^{2}$ and Tamer M. Abd Elaziem ${ }^{*}$ \\ ${ }^{1}$ Tissue Culture Unit, Department of Genetic Resources, Desert \\ Research Center, Matareya, Cairo, Egypt \\ ${ }^{2}$ Genetics and Cytology Unit, Department of Genetic Resources, Desert \\ Research Center, Matareya, Cairo, Egypt \\ *E-mail: tamermahfouz86@yahoo.com
}

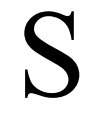

mooth cayenne pineapple cultivar is considered the most suitable variety for the climatic conditions in Egypt, in addition to its distinctive flavor and ability for canning. To meet market demand, large quantities of plant materials are required, which cannot be obtained via traditional breeding methods. As a result, an in vitro technique was designed to increase the multiplication rate, rooting, and acclimatization of this unique pineapple variety. Thidiazuron (TDZ) at $2.0 \mathrm{mg} / 1$ proved to be superior for direct organogenesis rate. Half strength Murashige and Skoog (MS) medium containing $1.0 \mathrm{mg} / \mathrm{l}$ indole-3-butyric acid (IBA) in combination with $0.5 \mathrm{mg} / \mathrm{l}$ naphthalene acetic acid (NAA) improved the number and length of roots. Organogenesis has been accelerated from in vitro derived leaves and developed to healthy plantlets, which were acclimatized in the greenhouse. In order to investigate the effect of micropropagation on circadian rhythm, the circadian expression of Aco013229.1 was compared, which belongs to the MADS-box gene family, between the in vitro propagated plantlets and the in vivo-grown plants. The unaffected expression pattern of Aco013229.1 proposed that in vitro micropropagation did not affect the circadian cycling; hence, the CAM photosynthesis process was not interrupted. Moreover, the circadian expression of Aco013229.1 of the in vitro and in vivo-grown plants showed a similar pattern, strongly pointing at a stable circadian rhythm of the micropropagated plants and thus a well-maintained CAM photosynthesis. This gene family plays a significant role in a number of biological processes especially flowering.

Keywords: Ananas comosus, smooth cayenne, circadian rhythm, in vitro, organogenesis, thidiazuron 


\section{INTRODUCTION}

The pineapple Ananas comosus Merr. is the world's most important tropical fruit (Chen et al., 2019). It is the only Bromeliaceae genus that has been successfully cultivated (Huihuang et al., 2020). Its ability to use water efficiently by utilizing the crassulacean acid metabolism (CAM) photosynthesis process makes it a good fit for dry lands (Ming et al., 2015 and Zhang et al., 2020). In CAM photosynthesis, plants store carbon dioxide during night and use it in photosynthesis during day to avoid losing water via gaseous exchange in opening stomata, thus, increasing the plant's ability to tolerate drought for longer periods of time. However, the molecular regulators of CAM photosynthesis are still largely unexplored. The MADS-box gene family, for example is known for its capacity to attach to DNA (Ming et al., 2015). This process is orchestrated by the circadian clock (Ming et al., 2015 and Zhang et al., 2020). Flower formation in pineapple plants is influenced by two key factors: short days and low temperatures (Maruthasalam et al., 2010). The chemical composition of pineapple (sugars, organic acids, minerals, fiber, aromatic compounds, vitamins, amino acids, flavonoids, carotenoids, etc.) depends greatly on the variety. It contains very good amounts of vitamin B6 (pyridoxine), niacin, riboflavin and folic acid. Moreover, pineapple fruit is rich in minerals with high biological activity (Assumi and Jha, 2021). In addition, as compared to other cultivars, smooth cayenne had the largest content of bioactive compounds, antioxidant capacities, and bromelain production in terms of biochemical properties (Viana et al., 2013).

Traditional vegetative propagation of pineapple causes disease spread, lack of uniformity, and inadequacy for commercial processing, both of which create a bottleneck in meeting global pineapple fruit demand. Obtaining materials from the pineapple sucker, crown, and slips using conventional techniques will take up to 16 to 18 months after the fruit is harvested. Furthermore, plant material transported from other countries is very pricey (Hamid et al., 2013). Besides which, by using the traditional propagation process, the multiplication rate of pineapple is low. Suppliers are struggling to satisfy the high demand for pineapple planting supplies as a result of this. In vitro propagation, on the other hand, has emerged as a vital solution for obtaining disease-free, rapid, standardized, and mass production of pins. Many authors have reported successful production of pineapple via micropropagatiom (Firoozabady and Gutterson, 2003 and Demissie et al., 2009). Hence, the multiplication rates and tissue culture techniques need to be improved for pineapple (Almeida et al., 2002).

As a result, the current research looked into the effect of plant growth regulators on in vitro proliferation, rooting, and greenhouse acclimatization of pineapple plantlets, as well as the expression of the flowering gene.

Egyptian J. Desert Res., 71, No. 2, 191-208 (2021) 


\section{MATERIALS AND METHODS}

Explants of pineapple (Ananas comosus cv. smooth cayenne) were obtained from a pineapple plantation on the Cairo-Alexandria desert road's horticulture field. The first step after removing buds from the parent plant is disinfestation, which removes any microorganisms present and reduces the risk of fungal and bacterial contamination.

These buds were sterilized in a laminar flow chamber under completely aseptic conditions, eliminating excess tissue before being placed into the culture medium. The buds were carefully submerged in fungicide for 10 min after being cleaned with sterilized water to remove dust and dry matter. Pineapple buds were sterilized for 20 min with $30 \%$ Clorox $(5.2 \%$ sodium hypochlorite solution) and then $0.2 \%$ mercuric chloride $\left(\mathrm{HgCl}_{2}\right)$ for $10 \mathrm{~min}$ with a few drops of Tween 20 , before being rinsed three times with sterile distilled water.

Murashige and Skoog (1962) basal salts were used to make the media, which included $2.7 \mathrm{~g} / \mathrm{l}(\mathrm{w} / \mathrm{v})$ phytagel and $30 \mathrm{~g} / 1$ sucrose. Prior to phytagel supplementation and homogenization, the $\mathrm{pH}$ of the medium was adjusted to 5.8 with $1 \mathrm{~N} \mathrm{NaOH}$ or $0.1 \mathrm{~N} \mathrm{HCl}$. After dispensing $40 \mathrm{ml}$ into jars, they were autoclaved for $20 \mathrm{~min}$ at $1.06 \mathrm{~kg} / \mathrm{cm}^{2}$ and $121^{\circ} \mathrm{C}$. Sterilized buds were cultured on MS medium without plant growth regulators and incubated at $25 \pm 2^{\circ} \mathrm{C}$ under 16 hours photoperiod provided by white fluorescent lamps.

\section{Effect of Three Various Cytokinins on the Mean Number of Adventitious Buds from Leaf (Organogenesis Process)}

For this experiment (organogenesis process), regenerated leaves from bud cultures were used as explants. The organogenesis medium was MS basal salts with vitamins supplemented with $30 \%$ sucrose, $2.7 \mathrm{~g} / 1$ phytagel, thidiazuron (TDZ; N-phenyl-N'-1,2,3-thidiazol-5-yl urea), Kinetin (KIN; 6furfurylaminopurine) and 6-(4-Hydroxy-3-methylbut-2-enylamino) purine (Zeatin) at $0.0,0.25,0.5,1.0,2.0$ and $4.0 \mathrm{mg} / \mathrm{l}$. After six and twelve weeks, mean number and length of adventitious buds/explant were recorded.

\section{Influence of Light Intensity on the in Vitro Growth and Development (Proliferation Stage)}

The aim of this experiment was to examine the influence of light intensity on the growth of pineapple at the multiplication stage. Cluster (contains three shoots) were grown on MS basal nutrient medium supplemented with $2 \mathrm{mg} / \mathrm{l}$ 6-benzyl adenine (BA), $30 \mathrm{~g} / 1$ sucrose, and $2.7 \mathrm{~g} / 1$ phytagel. At 16 hours photoperiod a day, all culture jars were incubated at 25 $\pm 2^{\circ} \mathrm{C}$ in light provided by white fluorescent tubes with intensities of around 1000, 2000, 3000, or 4000 lux. The intensity of light emitted was measured by digital lux meter. Mean number of axillary shoots/ explant, mean length of axillary shoots and mean length of leaves were recorded. 


\section{Effect of MS Strength with Auxins on the Rooting Stage}

The aim of the rooting stage is to prepare the plantlets for the establishment outside the artificial closed atmosphere of culture vessels. Each individual shoot was separated and transferred to a rooting medium in a culture tube or jar for root induction. Full-strength or half-strength MS basal medium with vitamins, supplemented with or without growth regulators, was used as the rooting medium. Indole-3-butyric acid (IBA) and naphthalene acetic acid (NAA) at $0.25,0.5,1.0,1.5$, and $2.0 \mathrm{mg} / \mathrm{l}$ were used sparingly in the medium. After six weeks, the mean number of roots per shoot, root length, and shoot height were recorded.

4. Effect of MS Strength with IBA and NAA and Their Combinations on Enhancing Rooting

Each medium supplemented with IBA at $0.0,0.5$, and $1.0 \mathrm{mg} / 1$ in combination with NAA at $0.0,0.25$, and $0.5 \mathrm{mg} / 1$ was used to reinforce the rooting of pineapple using MS medium at two salt concentrations (full and half). After six weeks, the mean number of roots/shoot, root length, and shoot height were recorded.

\section{Effect of Acclimatization Mixture on the Acclimatization Stage}

The adaptation stage includes shifting the plantlets from the aseptic culture system to the greenhouse's free-living environment, and then to the final site. Rooted plants were planted in pots containing a sterile soil of peat moss and sand in proportions of 1:1, 1:2, 2:1, and 2:2, respectively, then covered with a transparent polypropylene package and kept in the greenhouse for six weeks. After two weeks, one pore in the package was created, followed by another at four weeks, and eventually, at the end of six weeks, the package was removed and the plants were transferred to the open field. After six weeks, the percentage of survived plantlets, the mean length of plantlets, and the number of leaves per plantlet were noted.

\section{RNA Extraction}

To isolate total RNA from pineapple plantlets, samples (approximately $20 \mathrm{mg}$ ) were frozen in liquid nitrogen. Using mortar and piston, samples were homogenized and transferred to a $1.5 \mathrm{ml}$ centrifuge tubes. Further processing was performed using the RNeasy R Plant Mini Kit (QIAGEN, Hilden, Germany) following the manufacturer's instructions. The RNA was eventually eluted with RNase-free water.

\section{7. cDNA Synthesis}

cDNA was synthesized using SuperScriptTMII Reverse Transcriptase (RT) (Invitrogen) following the supplier's instructions. In short, $1 \mu \mathrm{L}$ Oligo (dT) primers, 500-1000 ng RNA and $1 \mu \mathrm{L}$ dNTP mix was incubated for 5 min at $65^{\circ} \mathrm{C}$. Reaction buffer $(1 \times)$ and $10 \mu \mathrm{M}$ DTT were added. Samples were 
incubated at $42^{\circ} \mathrm{C}$ before addition of the RT. The synthesis was performed over $60 \mathrm{~min}$ with heat inactivation of the enzyme for $15 \mathrm{~min}$ at $70^{\circ} \mathrm{C}$.

\section{Quantitative Real-Time PCR (qRT-PCR)}

Transcript analysis was performed by using cDNA corresponding to $500 \mathrm{ng}$ RNA from three biological replicates. SYBR green assays were developed using $\mathrm{iQ}^{\mathrm{TM}} \mathrm{SYBRR}^{\circledR}$ Green Supermix (Bio-Rad, Hercules, USA) with gene-specific primers. The reaction set up was adjusted to a total volume of $25 \mu \mathrm{l}$ with $12.5 \mu \mathrm{l}$ iQ SYBR Green Supermix, $1 \mu \mathrm{l}$ of each primer at $10 \mu \mathrm{M}$ and $10 \mu \mathrm{cDNA}$ template. PCR was performed on 'iQ5 multicolor real-time PCR detection system (Bio-Rad). Expressions were calculated using the CT method (Schmittgen and Livak, 2008). The gene of an expressed protein (Ananas $\beta$-Actin) served as internal control. This was previously proposed as reference gene (Luan et al., 2020).

\section{Data Analysis}

Analysis of variance (ANOVA), a statistical analysis program, was used to perform data variance analysis. Duncan's multiple range test (Duncan, 1955). was used to see if the differences between means for all treatments were significant at the $5 \%$ level. At $P \leq 0.05$, means preceded by the same letter are not substantially different.

\section{RESULTS}

However, there are several concerns with this plant's proliferation. Pineapple is limited by poor efficiency, disease vulnerability, and higher development costs. Micropropagation methods have been successfully used to resolve certain limitations in different crops, as well as ornamental and horticultural plants, in recent years. After eliminating the dust from the buds and disinfecting them with different disinfectant materials such as $\mathrm{HgCl}_{2}$ and Clorox, the buds were found to be healthy ( $70 \%$ survival) and contaminationfree $(100 \%)$, and they were then cultured in MS medium.

\section{Effect of Three Various Cytokinins on the Number of Adventitious Buds from Leaf (Organogenesis Process)}

Data in table (1) and fig. (1) illustrate the effect of MS medium containing different concentrations of cytokinins on the differentiation of organs (adventitious buds) from in vitro derived young leaves. All concentrations of TDZ, KIN and Zeatin showed shoot proliferation from leaves ranged between 10 and 61 buds/ explant. For instance, after 6 weeks, MS medium augmented with $2.0 \mathrm{mg} / 1 \mathrm{TDZ}$ produced the highest number of shoots development from the leaves and formed a cluster of 44 adventitious buds/explant, followed by Zeatin at $2.0 \mathrm{mg} / 1$, compared with the other treatments. The control treatment and the low concentrations of KIN recorded the lowest number of buds (10 buds/ explant). However, the length of the shoots in all treatments was the same $(0.5 \mathrm{~cm})$. 
Table (1). Effect of various concentrations of TDZ, KIN, and Zeatin on the differentiation of pineapple leaves into shoots.

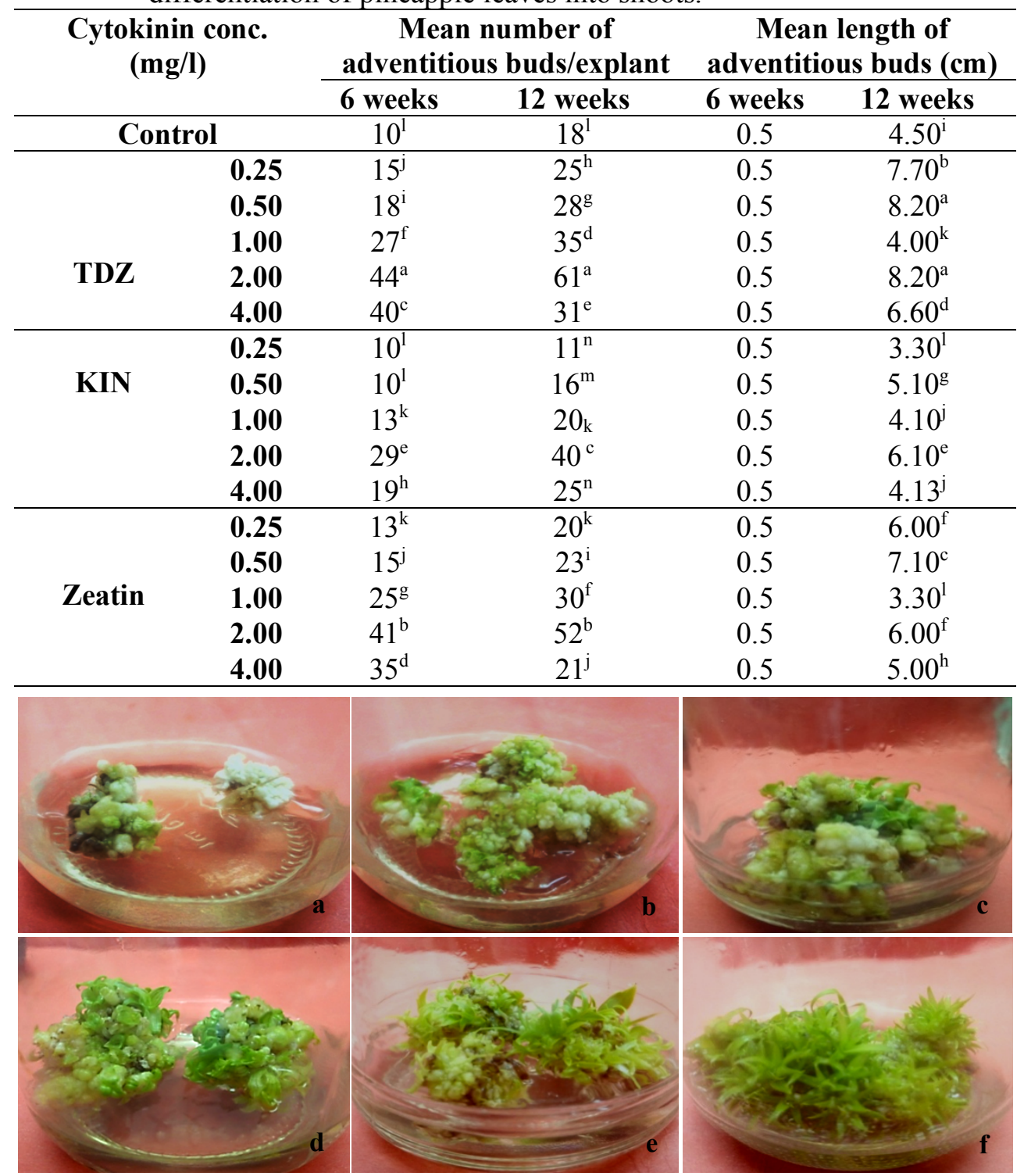

Fig. (1). In vitro regeneration via direct organogenesis from proximal leaf explant of pineapple smooth cayenne cultivar. a. Swilling of leaf buds. b. and c. Organogenesis induction from explants cultured on medium containing $2.0 \mathrm{mg} / 1 \mathrm{TDZ}$. d. Development of organs cultured on medium containing $2.0 \mathrm{mg} / \mathrm{l} \mathrm{TDZ}$ after 6 weeks. e. Developed shoots. f. Advanced shoot formation after the second subculture. 


\section{Influence of Light Intensity on in Vitro Growth and Development (Proliferation Stage)}

The effect of light intensity (500, 1000, 2000, 3000, and 4000 lux) on the growth and production of shoots and leaves of pineapple cultured in vitro is represented in table (2) and fig. (2). When pineapple shoots were incubated under white fluorescence lamp at intensities of 4000 and 3000 lux (for 16 hours daily) at $25 \pm 2^{\circ} \mathrm{C}$, the maximum significant shoot number/explant was achieved with significant difference in between (61 and 48 shoots/explant, respectively).

Table (2). Effect of light intensity on growth and development of pineapple cultured in vitro.

\begin{tabular}{cccc}
\hline $\begin{array}{c}\text { Light intensity } \\
\text { (lux) }\end{array}$ & $\begin{array}{c}\text { Mean number } \\
\text { of axillary } \\
\text { shoots/explant }\end{array}$ & $\begin{array}{c}\text { Mean length } \\
\text { of axillary } \\
\text { shoot }(\mathbf{c m})\end{array}$ & $\begin{array}{c}\text { Mean length } \\
\text { of leaves }(\mathbf{c m})\end{array}$ \\
\hline $\mathbf{5 0 0}$ & $11^{\mathrm{e}}$ & $5.3^{\mathrm{a}}$ & $4.06^{\mathrm{e}}$ \\
$\mathbf{1 0 0 0}$ & $25^{\mathrm{d}}$ & $5.0^{\mathrm{b}}$ & $5.20^{\mathrm{d}}$ \\
$\mathbf{2 0 0 0}$ & $40^{\mathrm{c}}$ & $4.4^{\mathrm{c}}$ & $6.10^{\mathrm{c}}$ \\
$\mathbf{3 0 0 0}$ & $48^{\mathrm{b}}$ & $4.0^{\mathrm{d}}$ & $6.40^{\mathrm{b}}$ \\
$\mathbf{4 0 0 0}$ & $61^{\mathrm{a}}$ & $3.5^{\mathrm{e}}$ & $7.06^{\mathrm{a}}$ \\
\hline
\end{tabular}

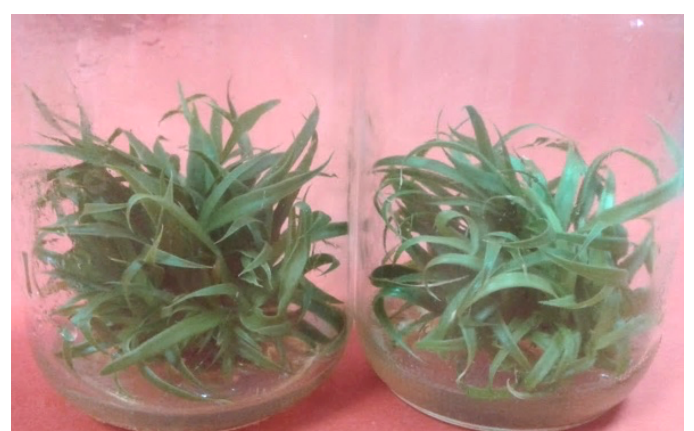

Fig. (2). Proliferation rate of pineapple under 4000 lux in vitro.

3. Effect of MS Strength (Full MS and $1 / 2$ MS) with IBA and NAA on Mean Number and Length of Roots and Mean Shoot Height during Rooting Stage

All of the shoots treated with IBA and NAA either full or half strength MS medium have a substantial impact on the mean number of roots/ explant mean length of roots $(\mathrm{cm})$, mean and shoot height $(\mathrm{cm})$, according to the data in (Table 3) and (Fig. 3). In comparison to complete MS medium, $1.5 \mathrm{mg} / \mathrm{l}$ NAA yielded the highest number of root/shoot (10.7) when used with $1 / 2 \mathrm{MS}$ (4.5). 
Table (3). Effect of full and half strength MS medium with different concentration of IBA and NAA on rooting of pineapple shoots.

\begin{tabular}{cccccccc}
\hline $\begin{array}{c}\text { Auxin conc. } \\
(\mathbf{m g} / \mathbf{l})\end{array}$ & \multicolumn{2}{c}{$\begin{array}{c}\text { Mean number of } \\
\text { roots/shoot }\end{array}$} & $\begin{array}{c}\text { Mean length of } \\
\text { roots } \\
\text { (cm) }\end{array}$ & \multicolumn{2}{c}{$\begin{array}{c}\text { Mean shoots } \\
\text { length } \\
(\mathbf{c m})\end{array}$} \\
\cline { 2 - 8 } & \multicolumn{2}{c}{ Full MS } & $1 / 2$ MS & Full MS & $1 / 2$ MS & Full MS & $1 / 2$ MS \\
\hline \multicolumn{2}{c}{ Control } & $2.0^{\mathrm{i}}$ & $6.0^{\mathrm{j}}$ & $0.25^{\mathrm{f}}$ & $0.5^{\mathrm{f}}$ & $2.0^{\mathrm{f}}$ & $2.60^{\mathrm{g}}$ \\
\hline & $\mathbf{0 . 2 5}$ & $1.0^{\mathrm{j}}$ & $7.0^{\mathrm{h}}$ & $0.50^{\mathrm{d}}$ & $0.8^{\mathrm{c}}$ & $2.4^{\mathrm{c}}$ & $3.30^{\mathrm{c}}$ \\
& $\mathbf{0 . 5 0}$ & $2.2^{\mathrm{g}}$ & $6.5^{\mathrm{i}}$ & $0.75^{\mathrm{a}}$ & $0.6^{\mathrm{e}}$ & $1.9^{\mathrm{g}}$ & $2.70^{\mathrm{f}}$ \\
$\mathbf{I B A}$ & $\mathbf{1 . 0 0}$ & $2.9^{\mathrm{d}}$ & $8.0^{\mathrm{e}}$ & $0.71^{\mathrm{b}}$ & $0.8^{\mathrm{c}}$ & $2.1^{\mathrm{e}}$ & $2.80^{\mathrm{e}}$ \\
& $\mathbf{1 . 5 0}$ & $2.3^{\mathrm{f}}$ & $7.23^{\mathrm{f}}$ & $0.41^{\mathrm{e}}$ & $0.7^{\mathrm{d}}$ & $2.1^{\mathrm{e}}$ & $2.60^{\mathrm{g}}$ \\
& $\mathbf{2 . 0 0}$ & $2.1^{\mathrm{h}}$ & $7.0^{\mathrm{h}}$ & $0.41^{\mathrm{e}}$ & $0.7^{\mathrm{d}}$ & $2.0^{\mathrm{f}}$ & $2.33^{\mathrm{h}}$ \\
\hline NAA & $\mathbf{0 . 2 5}$ & $2.5^{\mathrm{e}}$ & $7.1^{\mathrm{g}}$ & $0.41^{\mathrm{e}}$ & $0.8^{\mathrm{c}}$ & $1.9^{\mathrm{g}}$ & $2.26^{\mathrm{h}}$ \\
& $\mathbf{0 . 5 0}$ & $4.4^{\mathrm{b}}$ & $8.9^{\mathrm{d}}$ & $0.53^{\mathrm{c}}$ & $1.3^{\mathrm{a}}$ & $2.7^{\mathrm{a}}$ & $4.20^{\mathrm{a}}$ \\
& $\mathbf{1 . 0 0}$ & $4.5^{\mathrm{a}}$ & $10.0^{\mathrm{b}}$ & $0.41^{\mathrm{e}}$ & $1.1^{\mathrm{b}}$ & $2.5^{\mathrm{b}}$ & $3.40^{\mathrm{b}}$ \\
& $\mathbf{1 . 5 0}$ & $4.5^{\mathrm{a}}$ & $10.7^{\mathrm{a}}$ & $0.41^{\mathrm{e}}$ & $0.8^{\mathrm{c}}$ & $2.2^{\mathrm{d}}$ & $3.26^{\mathrm{c}}$ \\
& $\mathbf{2 . 0 0}$ & $4.0^{\mathrm{c}}$ & $9.0^{\mathrm{c}}$ & $0.41^{\mathrm{e}}$ & $0.7^{\mathrm{d}}$ & $2.0^{\mathrm{f}}$ & $2.90^{\mathrm{d}}$ \\
\hline
\end{tabular}


Fig. (3). Rooting of pineapple in half-strength MS basal medium with 1.5 $\mathrm{mg} / 1 \mathrm{IBA}$.

4. Effect of MS strength (Full MS and $1 / 2$ MS) with IBA, NAA and their combinations on enhancing the rooting of shoots

The effect of full and $1 / 2$ strength MS medium fortified with IBA in combination with NAA on enhancing root formation of pineapple was reported in table (4) and fig. (4). Data revealed that $1.0 \mathrm{mg} / 1 \mathrm{IBA}$ with $0.5 \mathrm{mg} / 1$ NAA was the optimum treatment. This auxin combination in $1 / 2$ strength MS medium improved the number of roots $(14.0$ roots $/$ shoot $)$, root length $(8.0 \mathrm{~cm})$, and shoot height $(12.1 \mathrm{~cm})$, when compared to full strength MS medium, which produced 8.0 roots $/$ shoot with length of $4.9 \mathrm{~cm}$ and $6.1 \mathrm{~cm}$ shoot height. 
Table (4). Effect of MS medium (full and half strength) containing IBA in combination with NAA on enhancing pineapple roots.

\begin{tabular}{|c|c|c|c|c|c|}
\hline \multicolumn{2}{|c|}{$\begin{array}{l}\text { Auxin conc. } \\
(\mathrm{mg} / \mathrm{l})\end{array}$} & \multicolumn{2}{|c|}{$\begin{array}{l}\text { Mean number of } \\
\text { roots/shoot }\end{array}$} & \multicolumn{2}{|c|}{$\begin{array}{l}\text { Mean length of roots } \\
(\mathrm{cm})\end{array}$} \\
\hline IBA & NAA & Full MS & $1 / 2 \mathrm{MS}$ & Full MS & $1 / 2 \mathrm{MS}$ \\
\hline \multirow{3}{*}{0.00} & 0.00 & $2.0^{\mathrm{i}}$ & $2.3^{\mathrm{h}}$ & $0.25^{\mathrm{i}}$ & $0.5^{\mathrm{i}}$ \\
\hline & 0.25 & $2.9^{g}$ & $2.9^{g}$ & $0.4^{\mathrm{h}}$ & $0.7^{\mathrm{h}}$ \\
\hline & 0.50 & $4.4^{\mathrm{c}}$ & $6.0^{\mathrm{d}}$ & $0.5^{\mathrm{g}}$ & $1.0^{\mathrm{g}}$ \\
\hline \multirow[t]{3}{*}{0.50} & 0.00 & $2.2^{\mathrm{h}}$ & $3.5^{\mathrm{f}}$ & $0.75^{\mathrm{e}}$ & $1.2^{\mathrm{f}}$ \\
\hline & 0.25 & $4.0^{\mathrm{d}}$ & $7.0^{\mathrm{c}}$ & $1.0^{\mathrm{c}}$ & $1.8^{\mathrm{c}}$ \\
\hline & 0.50 & $3.0^{\mathrm{e}}$ & $5.0^{\mathrm{e}}$ & $0.9^{\mathrm{d}}$ & $1.5^{\mathrm{d}}$ \\
\hline \multirow{3}{*}{1.00} & 0.00 & $2.9^{f}$ & $6.0^{\mathrm{d}}$ & $0.7^{\mathrm{f}}$ & $1.7^{\mathrm{e}}$ \\
\hline & 0.25 & $5.0^{\mathrm{b}}$ & $9.0^{\mathrm{b}}$ & $2.0^{\mathrm{b}}$ & $3.8^{\mathrm{b}}$ \\
\hline & 0.50 & $8.0^{\mathrm{a}}$ & $14^{\mathrm{a}}$ & $4.9^{\mathrm{a}}$ & $8.0^{\mathrm{a}}$ \\
\hline
\end{tabular}

Fig. (4). Rooting stage of pineapple plantlets growing on MS medium with $1.0 \mathrm{mg} / 1 \mathrm{IBA}$ plus $0.5 \mathrm{mg} / 1 \mathrm{NAA}$.

\section{Effect of Soil Mixture on the Plantlets Acclimatization Stage}

Except for those adapted on peat moss, transfer of pineapple plantlets with sterile roots to greenhouse conditions demonstrated nearly $100 \%$ survival success for all treatments. Table (5) and fig. (5) show the outcome of peat moss: sand 2:1 and 2:2, which scored 85.3 and $76.6 \%$, respectively. Plants that adapted to 1 peat moss: 1 sand or 1 peat moss: 2 produced the most leaves (10 and 9 leaves/plantlet) and the tallest adapted plantlets of about 5 $\mathrm{cm}$ were ordered and cultured in the same mixture. 
Table (5). Effect of media composition (peat moss and sand) on acclimatization of pineapple.

\begin{tabular}{cccc}
\hline Soil mixture & $\begin{array}{c}\text { Survival percentage } \\
(\%)\end{array}$ & $\begin{array}{c}\text { Mean plant } \\
\text { height }(\mathbf{c m})\end{array}$ & $\begin{array}{c}\text { Mean number of } \\
\text { leaves/plant }\end{array}$ \\
\hline Peat moss: sand (1:1) & $100.0^{\mathrm{a}}$ & $5.00^{\mathrm{a}}$ & $10^{\mathrm{a}}$ \\
Peat moss: sand (1:2) & $100.0^{\mathrm{a}}$ & $5.00^{\mathrm{a}}$ & $9^{\mathrm{b}}$ \\
Peat moss: sand (2:1) & $85.3^{\mathrm{b}}$ & $2.66^{\mathrm{b}}$ & $8^{\mathrm{c}}$ \\
Peat moss: sand (2:2) & $76.6^{\mathrm{c}}$ & $2.30^{\mathrm{b}}$ & $6^{\mathrm{d}}$ \\
\hline
\end{tabular}

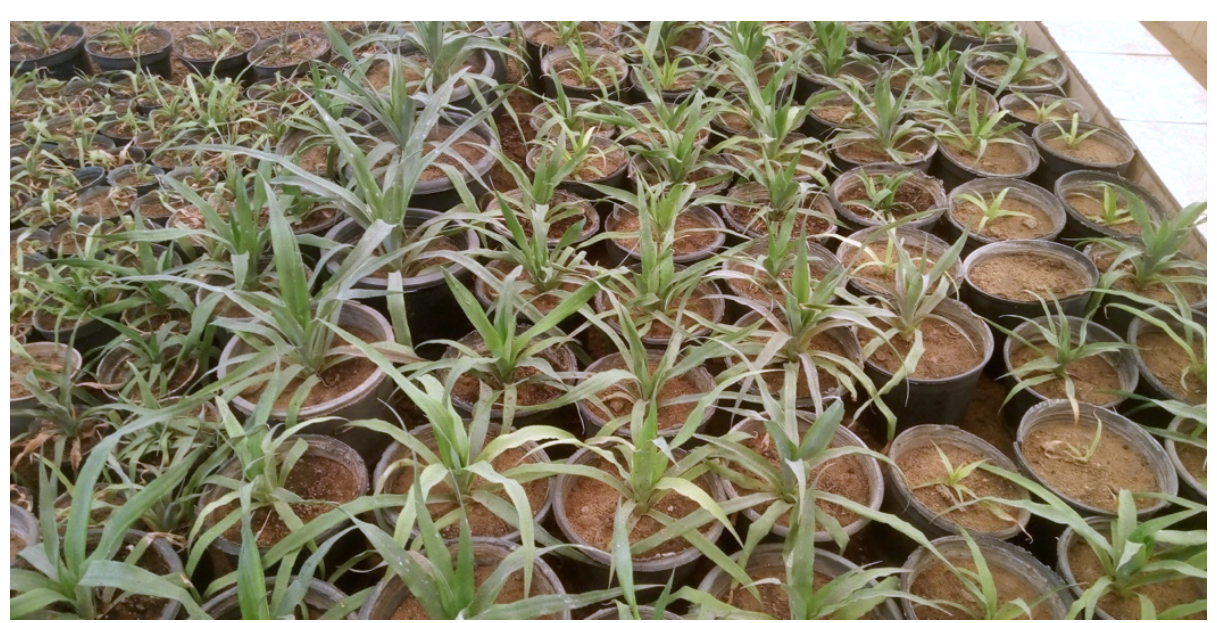

Fig. (5). Acclimatization of in vitro pineapple plantlets transplanted into peat moss: sand $(1: 1)$ after 12 weeks.

\section{Micropropagation does not have an effect on the circadian rhythm.}

In order to investigate the effect of micropropagation on circadian rhythm, the circadian expression of Aco013229.1 was monitored, which belongs to the MADS-box gene family. This family plays a significant role in a number of biological processes especially flowering. The members of this family share two highly conserved domains that encode for DNA-binding function. The gene expression of Aco013229.1 showed a circadian rhythm in pineapple plants that peaked around 10 am and significantly declined at $4 \mathrm{pm}$. Therefore, it was used to test the circadian cycling of the in vitro propagated plantlets. The qRT-PCR was used to measure the expression of Aco013229.1 in the in vitro- and in vivo-grown plants at two time points; 10 am and $4 \mathrm{pm}$ over two days. The expression pattern of Aco013229.1 in both in vitro- and in vivo-grown plants peaked at $10 \mathrm{am}$ and declined at $4 \mathrm{pm}$ similarly (Fig. 6). This proposes that in vitro micropropagation did not affect the circadian cycling, hence, the CAM photosynthesis process is not interrupted. 


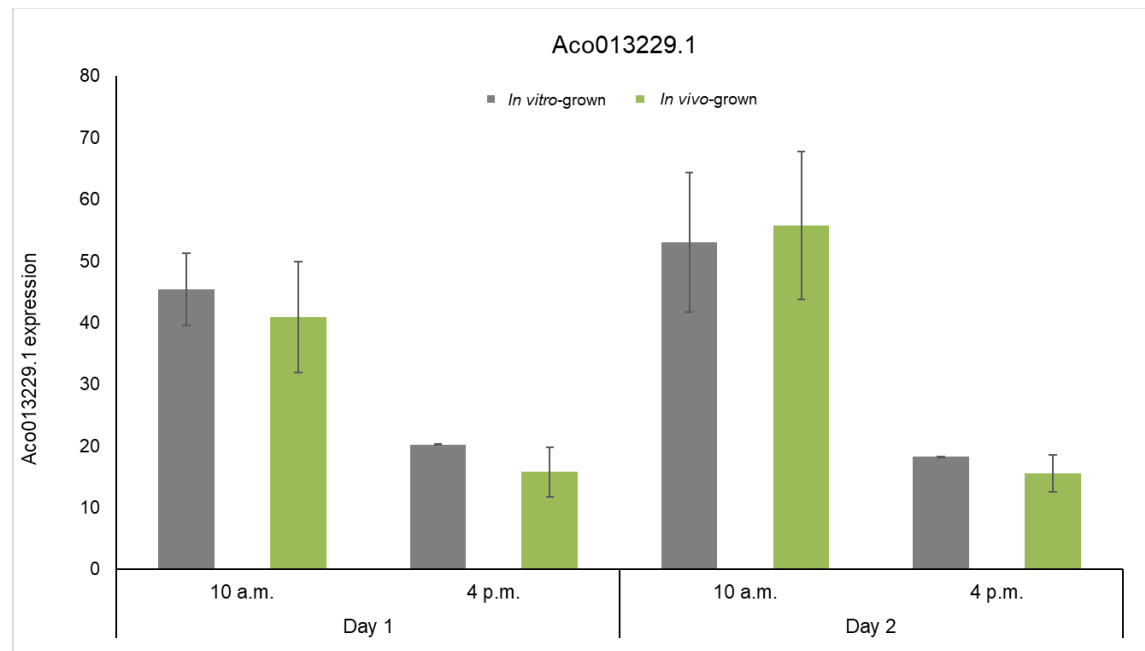

Fig. (6). Expression pattern of Aco013229.1 in in vitro- and in vivo-grown pineapple plantlets showing circadian cycling.

\section{DISCUSSION}

The in vitro technique's performance as a tool for plant propagation is highly dependent on the properties of the media utilized (Saad and Elshahed, 2012 and Arab et al., 2014). Explants grown in vitro have comparable basic needs as whole plants. As a result, George and De Klerk (2008) proposed that the culture media supply not only macro and micro nutrients, but also carbohydrate in the form of sucrose to replace carbon that would otherwise be acquired from the atmosphere. When vitamins, amino acids, and plant growth regulators are included in the culture media, better results will be attained (Kadhimi et al., 214 and Swamy et al., 2014). The medium used in this study has all of these components.

The presence of TDZ was found to be critical for organogenesis of pineapple, and this finding is consistent with Hassan et al. (2017), who found that MS medium supplemented with $1.0 \mathrm{mg} / \mathrm{l} \mathrm{TDZ}$ combined with auxin produced the highest proportion of direct shoot buds and direct embryos formation. TDZ is a phenylurea-type compound with cytokinin-like physiological activity (Sakakibara, 2004). Leaf bases, according to Firoozabady and Moy (2004), may include meristematic regions or newly formed tissue with rapidly dividing cells that are amenable to morphogenesis in tissue culture. TDZ treatments also improved endogenous auxin, ethylene, and ABA levels (Murthy et al., 1995 and Hutchinson et al., 1996). Interestingly, combining $0.5 \mathrm{mg} / \mathrm{l} \mathrm{TDZ}$ with $1.0 \mathrm{mg} / 1 \mathrm{BA}$ improved peroxidase activity during budding of date palm cv. Hillawi, where peroxidase activity was linked to the formation of more buds (Al-Mayahi, 2014). These findings were consistent with those of Taha et al. (2021), who used various 
combinations of cytokinins such as N6-(2-isopentenyl) adenine (2iP), KIN, $\mathrm{BA}$, and others on three date palm inflorescences (TDZ). In all three cultivars, TDZ alone or in combination with BA was found to be superior for direct organogenesis, so a new TDZ-BA combination was tested. TDZ at $2.0 \mathrm{mg} / 1$ could induce shoot in Urginea altissima leaf tissues (Baskaran et al., 2018), $1.5 \mathrm{mg} / \mathrm{l}$ in Passiflora miniata (Carvalho et al., 2019), and $1.0 \mathrm{mg} / \mathrm{l}$ in Aloe vera leaf tissues (Lavakumaran and Seran, 2014). TDZ at 0.5 and $5.0 \mu \mathrm{M}$ was found to be optimum for inducing an average of 4-5 shoots per cotyledonary node in $93 \%$ of the cultures and 55 somatic embryos in $68 \%$ of the cultures by Chhabra et al. (2008). According to Nsibande and Zhu (2017), the medium supplemented with $1.1 \mathrm{mg} / 1 \mathrm{TDZ}$ produced the highest shoot regeneration rate (75\%) of Hypoxis species. Many scientists have attempted to reason out how TDZ works in plants. Dey et al. (2012), for example, believe that TDZ causes cells in the apical meristem to divide and multiply, then mature, resulting in bud differentiation. According to Mundhara and Rashid (2002), calcium stress triggers TDZ's ability to induce shoot bud production in the dark, which affects ethylene production. The metabolism of endogenous growth regulators is closely linked to the role of TDZ in morphogenesis.

The positive effect of high light intensity on the proliferation of pineapple shoots is confirmed by Chen et al. (2019), who found that using 1.0 $\mathrm{mg} / 1 \mathrm{BA}+0.1 \mathrm{mg} / \mathrm{l} \mathrm{NAA}$ and a light intensity of $10 \mu \mathrm{mol} \mathrm{m}^{-2} \mathrm{~s}^{-1}$ resulted in the highest callus proliferation index (93.15\%). Under a light intensity of 45 $\mu \mathrm{mol} \mathrm{m}{ }^{-2} \mathrm{~s}^{-1}$, the best shoot proliferation rates were on media of either $1 \mathrm{mg} / 1$ BA + 0-0.4 mg/l NAA (65.57-81.01\%). When adventitious shoots were cultured on MS medium with $0.4 \mathrm{mg} / 1 \mathrm{NAA}+0.4 \mathrm{mg} / 1 \mathrm{IBA}$, the maximum root length $(15.57 \mathrm{~mm})$ and the highest rooting frequency (17 roots per shoot) were obtained. Plant hormones influence changes in plant physiology and morphogenesis that are caused by light intensity or quality (Kissoudis et al., 2017).

The ratio of auxin to cytokinin during in vitro propagation might be important in inducing the morphogenic response in higher plants (García et al., 2008). Explants, in general, require cytokinin to develop and auxin to produce roots. Auxins and cytokinins are crucial for regulating growth and promoting callus development in micropropagation.

Auxins like NAA, IBA, or a combination of NAA and IBA to the medium helped improving pineapple rooting in vitro. The addition of IBA in combination with NAA to the culture media is one of the variables that contribute to the effectiveness of root formation and the production of healthy pineapple plantlets. The fact that these growth regulators can act in concert or synergistically for the induction of in vitro roots may have contributed to the significant increase in the mean number of roots produced when NAA and IBA were used together (Danso et al., 2008). The presence of NAA in the rooting medium increased the number of rooting embryos in date palms. The greatest root thickness was achieved using NAA or IBA at $0.4,0.6$, or $0.8 \mathrm{mg} / 1$

Egyptian J. Desert Res., 71, No. 2, 191-208 (2021) 
with $60 \mathrm{~g} / \mathrm{l}$ sucrose. NAA has an effect on the principal root length, and IBA has an effect on the lateral root length, according to Fatima and Anis (2012). Shoots of geranium were rooted on MS medium supplemented with $0.2 \mathrm{mg} / 1$ of NAA, according to Hutchinson et al. (1996). Similarly, Akin-Idowu et al. (2014) revealed that a half-strength MS basal medium supplemented with 0.9 $\mathrm{mg} / \mathrm{l} \mathrm{NAA}$ alone resulted in the maximum mean number of roots per shoot (approximately 7.9). In the same way, acclimating MD2 pineapple rooted plantlets in jiffy peatmoss pots resulted in maximum growth and greenhouse establishment (Danso et al., 2008). On the other hand, Amin et al. (2005) and Tavares et al. (2008) successfully constructed pineapple and bromeliad plantlets on sand. These findings were in line with those of Atawia et al. (2016), who found that adapted plants survived $100 \%$ of the time when peatmoss: sand 1:2 was used. The survival rate of pineapple plantlets with sterile roots in greenhouse conditions was nearly $100 \%$ (Zuraida et al., 2011).

Over two days, qRT-PCR was applied to evaluate the expression of Aco013229.1 in the in vitro- and in vivo-grown plants at two different time points: 10 am and $4 \mathrm{pm}$. Aco013229.1 expression peaked about 10 am and then dropped considerably by $4 \mathrm{pm}$. This finding fits as well with previous studies where the circadian expression of Aco013229.1 showed a similar pattern (Zhang et al., 2020). This gene family is involved in a variety of biological activities, particularly flowering. The aforementioned circadian expression of Aco013229.1 in the in vitro-grown indicates that the circadian clock is not interrupted as a result of micropropagation. In previous, studies the circadian clock orchestrated the CAM photosynthesis which, subsequently, increases the water use efficiency by pineapple plants (Ming et al., 2015 and Zhang et al., 2020). The findings of this study propose a functional circadian clock, which would maintain the CAM photosynthesis process, hence, helps the in vitro-produced plants to efficiently use water.

\section{CONCLUSIONS}

In this work, unique growth regulator sequences were developed that were incorporated in the nutritional medium for pineapple (Ananas comosus) direct organogenesis from in vitro leaves explant. TDZ is important cytokinin to add to pineapple induction and multiplication medium. Smooth cayenne variety has shown to be a promising cultivar for micropropagation and biotechnology, and its shoots have grown into vigorous plantlets that have acclimatized in the greenhouse.

Aco013229.1 gene expression in the in vivo- and in vitro-grown plantlets exhibited a similar pattern in this research. This suggests that in vitro micropropagation had no effect on circadian cycling, and therefore the CAM photosynthesis mechanism was unaffected. This photosynthesis strategy improves the ability of pineapple plants to efficiently use water. This family is involved in several biological processes, including flowering. 


\section{REFERENCES}

Akin-Idowu, P.E., S.O.S. Akinyemi and D.O. Ibitoye (2014). Influence of medium type and growth regulators on in vitro micropropagation of pineapple (Ananas comosus (L.), var. smooth cayenne). African Journal of Plant Science, 8 (9): 450-456.

Al-Mayahi, A.M.W. (2014). Thidiazuron-induced in vitro bud organogenesis of the date palm (Phoenix dactylifera L.) cv. hillawi. African Journal of Biotechnology, 13: 3581-3590.

Almeida, W., G. Santana, A. Rodriguez and M. Costa (2002). Optimization of a protocol for micropropagation of pineapples. Rev. Bras. Fruit, 2: 296-300.

Amin, M.N., M.M. Rahman, K.W. Rahman, R. Ahmed, M.S. Hossain and M.B. Ahmed (2005). Large scale regeneration in vitro from derived callus cultures of pineapple (Ananas comosus L. (Merr.) cv. giant kew). International Journal of Botany, 1 (2): 128-132.

Arab, M.M., A. Yadollahi, A. Shojaeiyan, S. Shokri and S.M. Ghojah (2014). Effects of nutrient media, different cytokinin types and their concentrations on in vitro multiplication of $\mathrm{G} \cdot \mathrm{N} 15$ (hybrid of almond $\bullet$ peach) vegetative rootstock. Journal of Genetic Engineering and Biotechnology, 12: 81-87.

Assumi, S. P.T. and A.K. Jha (2021). Pineapple (Ananas comosus L. Merr.). book: In: "Tropical Fruit Crops: Theory to Practical". (Ghosh, S.N. and R.R. Sharma Eds.), pp. 487-541.

Atawia, A.R., F.M. Abd El-Latif, S.F. El-Gioushy, S. Saied and O.M.A. Kotb (2016). Studies on micropropagation of pineapple (Ananas comosus L.). Middle East Journal of Agriculture, 5 (2): 224-232.

Baskaran, P., A. Kumari and J. Van Staden (2018). In vitro propagation via organogenesis and synthetic seeds of Urginea altissima (L.f.) Baker: a threatened medicinal plant. 3 Biotech, 8 (1). 18.

Carvalho, P.P., C.A. Antoniazzi, R.B. Faria, I.F. Carvalho, D.I. Rocha and M.L. Silva (2019). In vitro organogenesis from root explants of Passiflora miniata Mast., an Amazonian species with ornamental potential. Brazil Archives Biol. Technol., 62: e19170803.

Chen, Y.M, J.Z. Huang, T.W. Hou and I.C. Pan (2019). Effects of light intensity and plant growth regulators on callus proliferation and shoot regeneration in the ornamental succulent Haworthia. Botanical Studies, 60: 10 .

Chhabra, G., D. Chaudhary, M. Varma, M. Sainger and P.K. Jaiwal (2008). TDZ-induced direct shoot organogenesis and somatic embryogenesis on cotyledonary node explants of lentil (Lens culinaris Medik.). Physiol. Mol. Biol. Plants, 14 (4): 347-353.

Danso, K.E., K.O. Ayeh, V. Oduro, S. Amiteye and H.M. Amoatey (2008). Effect of 6-benzylaminopurine and naphthalene acetic acid on in vitro

Egyptian J. Desert Res., 71, No. 2, 191-208 (2021) 
production of MD2 pineapple planting materials Ghana. World Applied Sciences Journal, 3 (4): 614-619.

Demissie, Z.A., Tefera, W.M. Fellipe, A.T. Negawo and A.M. Adal (2009). In vitro multiplication of pineapple (Ananas comosus $\mathrm{L}$.) and cardamom (Elletaria cardamomum) in Ethiopia. Proceeding of the Second Biennial Conference of Ethiopian Horticultural Science Society, Addis Ababa, Ethiopia, pp. 9-18.

Dey, M., S. Bakshi, G. Galiba, L. Sahoo and S. Panda (2012). Development of a genotype independent and transformation amenable regeneration system from shoot apex in rice (Oryza sativa spp. indica) using TDZ. 3 Biotech, 2: 233-240.

Duncan, D.B. (1955). Multiple range and multiple F tests. Biometrices, 11: 142.

Fatima, N. and M. Anis (2012). Role of growth regulators on in vitro regeneration and histological analysis in Indian ginseng (Withania somnifera L.) Dunal. Physiol. Mol. Biol. Plants, 18: 59-67.

Firoozabady, E. and N. Gutterson (2003). Cost effective in vitro propagation methods for pineapple. Plant Cell Report, 21: 844-850.

Firoozabady, E. and Y. Moy (2004). Regeneration of pineapple via somatic embryogenesis and organogenesis. In Vitro Cell Dev. Biol. Plant, 40: 6774.

García, R.D., Z. Somonte, J. Zaldúa, A. Mena, R. López, R.M. Valdivia, A.D. Arencibia, K.Q. Bravo and P.D.S. Caligari (2008). Efficient regeneration and Agrobacterium tumefaciens mediated transformation of recalcitrant sweet potato (Ipomoea batatas L.) cultivars. Asia Pacific Journal of Molecular Biology and Biotechnology, 16 (2): 25-33.

George, E.F. and G.J. De Klerk (2008). The Components of Plant Tissue Culture Media I: Macro- and Micro-Nutrients. In "Plant Propagation by Tissue Culture". $3^{\text {rd }}$ Edition (George, E.F., M.A. Hall and G.J. De Klerk eds.). Springer, Dordrecht, The Netherlands, pp. 65-113.

Hamid, N.S., M.F.M. Bukhori and M. Jalil (2013). Direct and indirect plant regenerations of pineapple var. MD2 (Ananas comosus L.). Malaysian Applied Biology, 42 (1): 61-66.

Hassan, M.M., A.H.I. Abd-El Kareim, F.A. Hussein and I.M. Shams El-Din (2017). IBA and TDZ induced plant regeneration of date palm through immature female inflorescence culture. International Journal of Advances in Agricultural Science and Technology, 4: 1-16.

Huihuang, C., B. Hu, L. Zhao, D. Shi, Z. She, X. Huang, S. Priyadarshani, X. Niu and Y. Qin (2020). Differential expression analysis of reference genes in pineapple (Ananas comosus L.) during reproductive development and response to abiotic stress, hormonal stimuli. Trop. Plant Biol., 12: 67-77.

Hutchinson, M., S. Murch and P.K. Saxena (1996). Morphoregulatory role of thidiazuron: evidence of the involvement of endogenous auxin in 
thidiazuron-induced somatic embryogenesis of geranium (Pelargonium $\times$ hortorum Bailey). Journal of Plant Physiology, 149: 573-579.

Kadhimi, A.A., A.N. Alhasnawi, A. Mohamad, W.Y. Wan Mohtar and B.C.M.Z. Che Radziah (2014). Tissue culture and some of the factors affecting them and the micropropagation of strawberry. Life Science Journal, 11: 484-493.

Kissoudis, C., A. Seifi, Z. Yan, A.T.M. Islam, H. Van der Schoot, C.C.M. Van de Wiel, R.G.F. Visser, C.G. Van der Linden and Y. Bai (2017). Ethylene and abscisic acid signaling pathways differentially influence tomato resistance to combined powdery mildew and salt stress. Frontiers in Plant Science, 9 (7): 2009.

Lavakumaran, L. and T.H. Seran (2014). Effect of 6-benzyl-aminopurine and thidiazuron on in vitro shoot organogenesis of Aloe vera (L.) Burm. f. Chilean Journal Agricultural Research, 74: 497-501.

Luan, A., C. Chen, T. Xie, J. He and Y. He (2020). Methylation analysis of CpG islands in pineapple SERK1 promoter. Genes, 11 (4): 425.

Ming, R., R. Van Buren, C.M. Wai, H. Tang and M.C. Schatz et al. (2015). The pineapple genome and the evolution of CAM photosynthesis. Nature Genetics, 47 (12): 1435-42.

Maruthasalam, S., L.Y. Shiu, M. Loganathan, W.C. Lien, Y.L. Liu, C.M. Sun, C.W. Yu, S.H. Hung, Y. Ko and C.H. Lin (2010). Forced flowering of pineapple (Ananas comosus cv. Tainon 17) in response to cold stress, ethephon and calcium carbide with or without activated charcoal. Plant Growth Regul., 60: 83-90.

Mundhara, R. and A. Rashid (2002). Stimulation of shoot-bud regeneration on hypocotyl of Linum seedlings, on a transient withdrawal of calcium: effect of calcium, cytokinin and thidiazuron. Plant Science, 162: 211214.

Murashige, T. and F. Skoog (1962). A revised medium for rapid growth and bioassays with tobacco tissue cultures. Plant Physiology, 15: 473-497.

Murthy, B.N.S., S.J. Murch and P.K. Saxena (1995). Thidiazuron-induced somatic embryogenesis in intact seedlings of peanut (Arachis hypogaea): endogenous growth regulator levels and significance of cotyledons. Physiologia Plantarum, 94: 268-276.

Nsibande, B.E. and L. Zhu (2017). Developing an in vitro propagation method for mass production of medicinal Hypoxis species using bioreactors. Asian Journal of Plant Science and Research, 7 (4): 1-8.

Saad, A.I.M. and A.M. Elshahed (2012). Plant Tissue Culture Media. In: "Recent Advances in Plant in Vitro Culture" (Leva, A. and L.M.R. Rinaldi eds.), In Tech, Rijeka, Croatia, pp. 29-40.

Sakakibara, H. (2004). Cytokinin Biosynthesis and Metabolism. In: "Plant Hormones: Biosynthesis, Signal, Action". $3^{\text {rd }}$ Edition (Davies, P.J. ed.). Kluwer Academic Publishers, London, pp. 95-114.

Schmittgen, T.D. and K.J. Livak (2008). Analyzing real-time PCR data by

Egyptian J. Desert Res., 71, No. 2, 191-208 (2021) 
the comparative CT method. Nature Protocols, 3 (6): 1101-1108.

Swamy, M.K., S.K. Mohanty and M. Anuradha (2014). The effect of plant growth regulators and natural supplements on in vitro propagation of Pogostemon cablin Benth. Journal of Crop Science and Biotechnology, 17: 1-7.

Taha, R.A., M.A. Allam, S.A.M. Hassan, B.M.M. Bakr and M.M. Bakr (2021). Thidiazuron-induced direct organogenesis from immature inflorescence of three date palm cultivars. Journal of Genetic Engineering and Biotechnology, 19: 14.

Tavares, A.R., P. Giampaolo, S. Kanashiro, F.F.A. Aguiar and E.P. Chu (2008). Effect of foliar fertilization $\mathrm{KNO}_{3}$ in the acclimatization of bromeliads grown in vitro. Horticultural Brasileira, 26 (2): 175-179.

Zhang, X., M. Fatima, P. Zhou, Q. Ma and R. Ming (2020). Analysis of MADS-box genes revealed modified flowering gene network and diurnal expression in pineapple. BMC Genomics, 21 (1): 8.

Zuraida, A.R., A.H. Nurul Shahnadz, A. Harteeni, S. Roowi, C.M.Z. Che Radziah and S. Sreeramanan (2011). A novel approach for rapid micropropagation of maspine pineapple (Ananas comosus L.) shoots using liquid shake culture system. African Journal of Biotechnology, 10 (19): 3859-3866. 


\section{تأثير ظروف الإكثار الاقيق على تثكيل البراعم العرضية وتعبير أحد جينات الساعة البيولوجية Aco013229.1 في نبات البرات الأناناس}

منال الصلاة على النبي أحمد'، رضا السيد السيد أبو الفضل'، محمد نادي سيد سليمان'


'وحدة زر اعة الأنسجة، قسم الأصول الور اثية، مركز بحوث الصحر اء، المطرية، القاهرة، 'وحدة الوراثة والسيتولوجي، قسم الأصول الوراثية، مركز بحوث الصحراء، المطرية، القاهرة، مصرة الوراثة

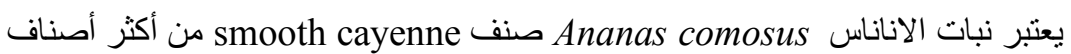

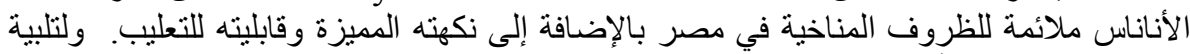

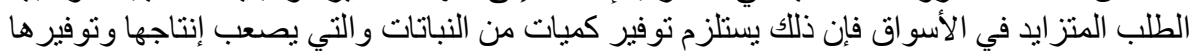

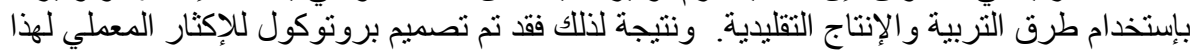

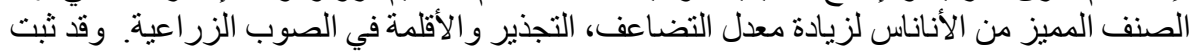

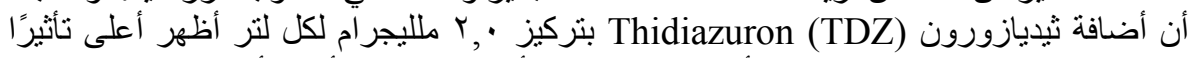

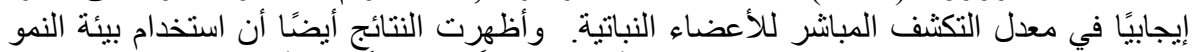

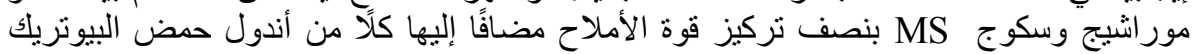

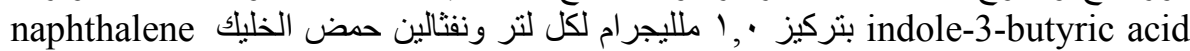
وطوكيز 0, acetic acid

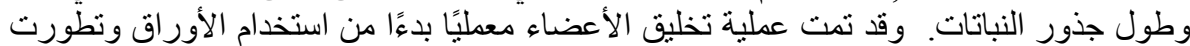

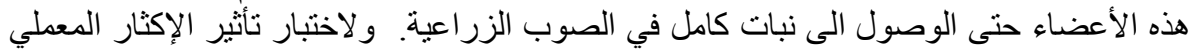



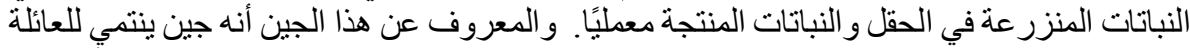

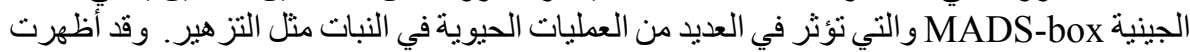



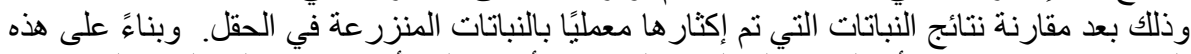

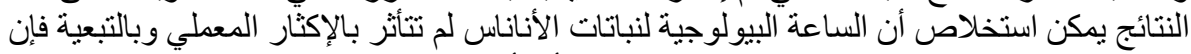





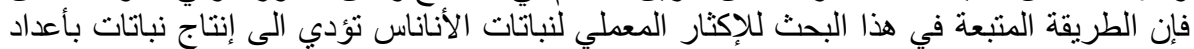



Egyptian J. Desert Res., 71, No. 2, 191-208 (2021) 